\title{
Promoting Positive Behaviours Using Sociodrama
}

\author{
Deanna Pecaski McLennan and Kara Smith \\ University of Windsor
}

\begin{abstract}
This study investigates whether the use of sociodramatic activities created by Augusto Boal can promote self-expression, a commitment to learning, and positive behaviour in grade eight students. Twenty-four "at-risk" students were identified by the school principal, and participated in ten weekly 45-minute drama sessions. Initially, participants exhibited behavioural problems such as a lack of motivation, multiple social problems, and a demonstrated lack of respect for peers and teaching staff. Data from the sessions were collected through participant journals, field notes, questionnaires, and member checks. Gender differences were observed in participation levels during activities and discussions. Student responses suggested that the use of sociodramatic techniques provided multiple opportunities for self-expression. Most girls in the study were involved in the dramatic activities and discussions on a consistent basis from the beginning, whereas most boys were inactive participants at the beginning, but increased their commitment and even assumed leadership roles by the conclusion of this study. Although changes in self-expression and commitment to learning may have been the result of students engaging in routinely scheduled drama activities, the study found that sociodrama activities based on Boal's work, when implemented in the classroom, could have the potential to encourage positive behaviour in at-risk students.
\end{abstract}

\section{Introduction}

Augusto Boal has used sociodrama as a way to examine and help resolve participants' individual and collective social problems (Boal, 1985; Schutzman \& Cohen-Cruz, 1994). "Theatre of the Oppressed" has been used by groups to motivate hope and raise self-esteem and self-awareness in order to examine issues such as poverty, loneliness, racism, sexism, political oppression, and aging (Grieco \& Chambliss, 2001; Schutzman \& Cohen-Cruz, 1994). As an action researcher and drama educator, I (Deanna) wanted to see if similar sociodrama activities and techniques could create positive change amongst principal- 
at-risk students within my school. Could the same activities and techniques be transferred and be as effective with a group of Caucasian, upper middle-class, North American, at-risk students?

Elementary educators in Ontario are required to include drama in the classroom as a part of their curriculum (Ministry of Education, 1998). Drama has been used in schools as an aid for the mental, physical, and emotional development of children (Larkin, 2001; Taylor, 1965). Dramatic activity emphasizes creativity, spontaneity, and self-expression, and is an ideal discipline to aid students in the development of self-concept (Garcia, 1993; Somers, 1996; Taylor, 1965). It is a rich, interactive art form that allows participants to express themselves in ways that they would not normally (Warren, 1993). These activities are practised in safe, nurturing environments where participants can explore real life personal feelings, issues and situations (Bieber-Schut, 1991; Way, 1967; Widdows, 1996).

Sociodrama, in particular, is an approach that allows participants to examine collective group or social problems through dramatic methods involving roleplay, improvisation, and tableau (Torrance, 1975). Participants choose social issues of importance such as racism, poverty, and pollution, and then propose, test and evaluate solutions to these problems through dramatic techniques. "In an effort to transform theatre from the 'monologue' of traditional performance into a 'dialogue' between audience and stage" (Paterson \& Weinber, 1996, p. 19) audience members are encouraged to interact with actors by suggesting changes in the dramatic action they are observing. This involvement empowers audience members because they are no longer passive viewers of the drama occurring on stage and differs from the more traditional theatrical techniques outlined in drama curriculum (Howard, 1994). Instead audience members, renamed spectactors, control the action and witness actors giving life to their ideas for change. This allows for a state of constant dialogue to exist between the actors on the stage and the audience members viewing the performance. Sociodramatic techniques derived from the dramatist Boal (1985) and his "Theatre of the Oppressed" can be powerful approaches for change (Schutzman \& Cohen-Cruz, 1994), and ergo, can be excellent techniques to use in the classroom. These tools were the foundation for the experimental workshops I conducted with Grade 8 students during 2003.

Boal (1985) states that theatre and drama encourage human interaction. This interaction creates an outlet for expression that encourages theatre practitioners to explore themselves, their peers, and their surroundings (Schutzman \& CohenCruz, 1994). Theatre techniques, such as improvisation and role-play, help create a place for people to invent and discover themselves, and the world around them. Through this dramatic experience a person can explore who they are, and imagine what they might be. This self-exploration provides opportunities to strengthen self-concept and self-esteem. Boal used his Theatre of the Oppressed techniques with oppressed members of society (Boal, 1985), but they have also been implemented successfully in many educational environments such as elementary and high school classrooms (Creel, Kuhne, \& Riggle, 2000; Johnson, 2001; Kaye \& Ragusa, 1998; Linds, 1998; O’Toole \& Burton, 2002). 


\section{Can Sociodrama Promote Positive Behaviour in At-Risk Students?}

The population of grade eight students involved in this study consisted of 24 students (13 boys and 11 girls). Participants were identified by their school principal as being "at-risk." Boys and girls participating in the sociodramas had all been identified as having persistent behavioural problems including: a lack of motivation, multiple social problems, and a demonstrated lack of respect towards their peers and teaching staff. As a way to help modify these behaviours, I [Pecaski McLennan] created and implemented a 10-week drama series to improve class relations and work habits. As a drama educator, I have always had a great interest in whether sociodrama-in particular, Theatre of the Oppressed activities-could be used in a classroom to aid students in positive self-expression and exploration. Because sociodrama activities and techniques have proven successful in educational environments (Creel, Kuhne, \& Riggle, 2000; Johnson, 2001; Kaye \& Ragusa, 1998; Linds, 1998; O’Toole \& Burton, 2002), I chose to use these techniques. The workshops consisted of ten 45-minute weekly sessions based on the work of Boal $(1985,1992)$. The activities were derived from Boal's Games for Actors and Non-actors (1992). Here, Boal emphasizes how drama and theatre activities might be used as tools for the transformation and personal liberation of participants. In Boal's work, dramatic expression, group problemsolving and personal risk-taking are emphasized.

During the drama sessions every effort was made to ensure that the environment was supportive and physically and psychologically safe for the students. Students need to feel comfortable in order to successfully participate in drama activities (Taylor, 1994; Way 1967). Way (1967) defines a safe drama space as a physically inviting environment large enough to allow students free movement in activities. This space should be secluded from the rest of the school, so that outsiders cannot influence the drama or cause anxiety in student performers. This area should be warm and have adequate lighting. A safe classroom environment is one where there is a level of comfort and trust within the group of participants so that they can freely explore issues, feelings, and unfamiliar situations (Blum, 1999; Way, 1967). Role-playing allows people the opportunity to develop self-concept through risk-taking and personal exploration. A safe environment encourages risk-taking because there is little threat of personal failure or feelings of discomfort. Drama can provide a forum for shared communication and adventure as students explore self-directed issues on a voluntary basis. The safe, inviting comfort zone created by the drama experience encouraged many male students in this study to find their individual voices. The findings in this study indicate which specific sociodramatic activities were particularly effective in eliciting positive behaviour from the principal-identified "at-risk" students.

Throughout the drama sessions, qualitative action research methods were used. In-depth, case-by-case data of 24 participants were collected through participant journals (written by participants after each drama session), daily researcher field notes, a pre and post Piers Harris Children's Self-Concept Scale (Adelman, Taylor, \& Nelson, 1989) that asked students to respond to questions such as "I am a happy person" (p.1) and "I have good ideas" (p.1), and research questionnaires that asked students to discuss the drama sessions and their 
personal reflections. Member checks were used with students to clarify their responses to the drama.

\section{Findings}

\section{Promotion of self-expression}

An analysis of the themes evident in the participants' journals, researcher's field notes, and the pre- and post-research questionnaires revealed that many students felt that the activities provided them with multiple opportunities for selfexpression and sharing their ideas and feelings, that they would normally not have in a regular classroom environment. This sentiment was prevalent in student responses in personal journals and questionnaires. Three changes were observed as the sociodramas progressed: (a) There were positive changes in students' selfexpression, (b) there was a commitment to the drama and the learning, and (c) positive behaviours were observed evolving.

Many of the students involved in the study indicated that they were provided with opportunities for positive self-expression. This sentiment was prevalent in student responses in the participants' journals and post questionnaires. The drama sessions that most often elicited positive, focused behaviour and responses from students were sessions 5 and 6 . In each session, students participated in a drama game called "The Fighting Chickens" (Boal, 1992, p. 160). This game was developed to facilitate improvisation, risk-taking, problem-solving, and communication skills between participants as there were no scripts or actions planned ahead of time. Students worked in either pairs or small groups. One student began the improvisation by accusing another student of having done something wrong. The other student then had to defend him- or herself and, at the same time, justify the action he or she had have been accused of. This process helped students practise risk-taking and problem-solving skills by requiring them to think quickly and spontaneously when either accusing another student or defending their own actions. Communication skills were strengthened as the improvised conversation between students progressed. The nature of this activity required students to be very clear and concise in their verbal interactions with each other. As a result, field notes and journal entries indicated that students learned to reflect upon and justify their actions more clearly than pre-activity communications. Students also became less defensive of their actions and more easily able to look upon criticism as an indication to reflect.

Another activity that elicited both positive behaviours and responses from students was "Complete the Image" (Boal, 1992, p. 130). In this game, students worked in groups of four or five. Two designated actors shook hands and froze. The remaining group members then brainstormed the possible symbolic meanings of the handshaking image (that is, a business meeting, friends parting forever, a baseball team). Once the group decided upon a meaning it was shared with the two actors who were shaking hands. Each person in the pair was then required to improvise two verbal lines to convey this meaning to the group. Similar to The Fighting Chickens, this activity required students to take risks and problem-solve in the dramatic activity through improvisation. Students indicated in personal journals and member checks that these activities were particularly 
meaningful. Following this activity, students were more capable of identifying body language; many were more accurate about identifying emotions. This allowed students the opportunity to consider their own body language and how teachers and peers may have been misinterpreting how they felt and vice versa. For example, one participant, Carl, stated that the drama provided him the opportunity "to express [himself] in different ways and be like [himself], not like someone else. [He] prefers small groups because you have more parts and you can do more things by yourself but still be in groups."

The theme of a positive opportunity for self-expression was also evident in the participant journals. Danielle wrote on a continuing basis about drama allowing her to feel more comfortable while presenting her ideas in front of the class. As the sessions continued and the boys in the group appeared more comfortable, they began to share more frequent expressions of self, feelings, and experiences.

With self-expression, came an increase of confidence where the participants indicated that the sociodramas made them feel more confident. Jocelyn wrote that she "liked the drama because it made [her] feel more confident in front of people." With the dramatic role-play and practice, it was now easier for students to read body language, interpret an array of emotions, accurately and positively voice their own emotions, and reflect upon and justify their actions.

Both "The Fighting Chickens" and "Complete the Image" activities elicited focused student engagement, an increase in positive behaviours and cooperation in the drama workshops, and positive responses in student journals, member checks, and interpersonal conversations. These activities provided students with the opportunity to explore personal areas of interest, conflict and emotion in a safe and supportive classroom environment. It seemed to formally recognize the genuine and difficult feelings the students were having in school. The improvised nature of the activities allowed students to be in control of both the drama and their level of engagement within the activity, providing multiple opportunities for both personal empowerment and self-expression.

\section{Promotion of leadership skills}

A great benefit from the sociodramas appeared to be the increased student commitment to learning and leadership. Throughout the drama sessions, there were distinct gender differences observed. The participation levels during activities and discussions differed according to gender. The most surprising observation was that the boys' participation levels and commitment to learning appeared to increase as the workshops progressed while most of the girls were involved from the beginning and remained so consistently.

The boys' increased commitment to the sociodramas was most noticeable following session 5 and 6 . Again, the activities in both of these sessions that appeared to have the most positive impact on students were "The Fighting Chickens" and "Complete the Image."

The boys led discussions, encouraged others to participate, and wrote about leadership in their journals. There were several boys and girls whose involvement was of particular interest. Bobby is an excellent example of a participant who evolved from an inattentive, distracted participant to that of a leader. Field notes reveal that with the progression of each session, Bobby's levels of concentration 
and engagement in activities appeared to increase. Throughout sessions 1 through 4 , Bobby was, on numerous occasions, disruptive to his peers, and unfocused in activities and discussions. He would yell at other students, make distracting noises to unsettle others in their individual work, and ignore instructions. In session 5, during the "Fighting Chickens" activity, his commitment to learning and leadership was born. He started to work cooperatively and participated actively in group activities. Later, his involvement in the sessions included helping with demonstrations of dramatic work and facilitating the discussions. Bobby would address and calm down his peers when some of them disrupted the sessions. His writings and discussions often reflected that he preferred the role of leader. He wrote: "I improved my leadership skills a lot by playing the games you taught us. Thanks a lot for helping me to improve my skills, I will surely use them later." After the workshop, Bobby would frequently share with me in person how much he enjoyed taking on a leadership role. Bobby was clearly more comfortable being a leader than a passive participant, and his behaviour improved as his energy was channelled in a more positive direction.

\section{Male Participation in Class Discussions}

Hattie (1992) indicates that an emphasis is needed to determine how educators can encourage adolescent boys to participate more in oral discussions and be more forthcoming in their expressions of self, feelings, and experiences. The sociodramatic workshops appeared to encourage boys like Bobby to do just that. O'Neill (1997) suggests that educational drama is a classroom tool that can be used to empower adolescent males. Siks (1983) states that drama encourages students to think, talk, and share viewpoints to arrive at their own decisions. The sociodrama techniques used in this study appeared to increase the participation level of boys in their expressions of self, personal ideas, and experiences.

As their commitment to learning increased, the boys began to assume leadership roles as well. Brayden, for example, stated in his written work that what he liked best was "taking a leadership role during the experiences." Although most girls participated consistently in activities, only one girl appeared to assume a leadership role. Jocelyn was an active participant from the start of the drama sessions. She became more interested in taking part in leadership roles around session 5, the same session that appeared to have a positive influence on the boys' level of involvement and leadership. Towards sessions 8, 9, and 10, Jocelyn began to reflect deeply upon her interest and level of involvement. She began to write detailed journal entries that discussed her work and feelings, and she began to have involved conversations outside of the drama classes regarding her participation in, and response to, the drama sessions.

Billy is another participant whose interest and involvement appeared to increase as the workshops progressed. He volunteered to lead his peers in games, activities, discussions, and demonstrations of specific dramatic techniques. Billy often encouraged and supported his peers in their own dramatic work. By the conclusion of the sessions, he frequently volunteered to discuss and present his work and ideas. Much like Brayden, Bobby, and Billy, there were a number of other participants whose involvement in group work and discussions increased. They also became leaders. 
As noted earlier, it was observed that many of the girls in this study were active participants. Numerous girls stated in their journals that they enjoyed participating in the activities, but preferred not to engage in leadership roles. Sarah wrote: "I liked other people being the leader because it's interesting to see their view on what the scene should look like, to my view." Many others also expressed similar thoughts. These girls appeared to be more interested in helping to empower the leader than assuming leadership themselves. Why did this occur? According to Lanoux and O'Hara (1999), pre-adolescent girls occasionally have difficulty finding their own voice and expressing themselves. Perhaps the girls in this class were reluctant to take part in leadership roles because they felt uncomfortable doing so. Lanoux and O'Hara state that drama and theatre are valuable tools for strengthening girls' self-images. Creative activities for safe self-expression can help pre-adolescent girls find their own voice and bring them into their own power. It appears that the sociodramatic activities encouraged boys in the class to share their ideas, feelings and experiences. Perhaps with girls, further opportunity for dramatic activities would foster added interest in leadership.

\section{Reluctant Student Participants}

A venue for positive self-expression, respecting others ideas, feeling more confident and developing a commitment to learning and leadership are all positive behavioural outcomes from the sociodramatic sessions and study. Some students, however, were reluctant to participate in any of the activities and took the role of observer, watching instead of participating. When students felt uncomfortable, they were given the opportunity to pass their turn and refrain from participation. These students chose to be spectators. McCaslin (2000) states that even as spectators, people observing dramatic activity are still compelled to think and feel more deeply about issues addressed within the dramatic framework. Perhaps these students were quietly examining personal beliefs, feelings, and experiences in relation to the activities explored by their peers. Although passive, these students could still be engaging in the dramatic activities (Boal, 1985; McCaslin, 2000). This appears to be one area for future exploration.

\section{Conclusion}

It may be stated from the findings in this study that sociodramatic activities can be implemented in educational environments. Sociodrama may encourage selfexpression in the form of idea sharing and confidence building; it may increase a commitment to learning and leadership, and, as a result, it may empower and help develop more positive behaviours within "at-risk" youth (Berry, 1998; Howard, 2004; Widdows, 1996). Students who participated in the dramatic activities learned (in the short term) to solve problems, make decisions, justify those decisions, build self-esteem and self-discipline, and acquire skills in cooperation and group problem solving such as accurately recognizing and displaying body language and emotions (Bieber-Schut, 1991; Garcia, 1993). In this study, students who participated in the weekly sociodrama sessions expressed that they began to feel more comfortable working with others and expressing themselves through a dramatic medium towards the end of the 
sessions. Field notes reveal that the expression of positive self-expression and participation in leadership roles extended beyond the drama classes as students were involved in more frequent and positive behaviours when walking in the hallways of the school or socializing during recess time. Educators who provide a regular schedule for drama within a safe and inviting environment may be providing opportunities for students to develop self-expression, to interact positively with peers, and to assume leadership roles. Sociodrama techniques, then, may be powerful classroom tools in promoting new awareness and change as students learn to express feelings, ideas and experiences, and perhaps even realize their leadership potential. This would hopefully lead to a better understanding of themselves and the world around them and to a more positive classroom environment.

\section{References}

Adelman, H.S., Taylor, L., \& Nelson, P. (1989). Minor's dissatisfaction with their life circumstances. Child Psychiatry and Human Development, 20, 135-147.

Al-Saadat, A. I., \& Afifi, E. A. (1997). Role-Playing for inhibited students in paternal communities. Forum, 35(3), 43-47.

Berry, D. (1998). Kids and art: Learning through the senses. Principal, 77, 28-34.

Biddulph, S. (1994). Boys in schools. Lane Cove, Australia: Finch Pub.

Bieber-Schut, R. (October, 1991). The use of drama to help visually impaired adolescents acquire social skills. Journal of Visual Impairment \& Blindness, 340-341.

Blum, L. (1999). Ethnicity, identity, and community. In M. Katz, N. Noddings, and K. Strike (Eds.), Justice and caring: The search for common ground in education (pp.127-145). New York: Teachers College Press.

Boal, A. (1985). Theatre of the oppressed. New York: Theatre Communications Group.

Boal, A. (1992). Games for actors and non-actors. New York: Routledge.

Cox-Petersen, A.M., \& Olson, J.K. (2000). Authentic science learning in the digital age. Learning and Leading With Technology, 27(6), 32-5, 61.

Creel, G., Kuhne, M., \& Riggle, M. (December, 2000). See the Boal, Be the Boal: Theatre of the oppressed and composition courses. TETYC, 141-156.

Garcia, L. (1993). Teacher beliefs about drama. Youth Theatre Journal, 8, 20-25.

Grieco, M., \& Chambliss, C. (2001). Educational methods for addressing diversity issues: The use of sociodramatic techniques. Pennsylvania: Ursinus College. (ERIC Document Reproduction Service N. ED456368).

Hattie, J. (1992). Self-concept. Mahwah, NJ: Erlbaum.

Howard, L. A. (2004). Speaking theatre/doing pedagogy: Re-visiting Theatre of the Oppressed. Communication Education, 53(3), 217-233.

Johnson, C. (2001). Helping children to manage emotions which trigger aggressive acts: An approach through drama in school. Early Child Development and Care, 116, 109-118.

Kaye, C., \& Ragusa, G. (1998). Boal's Mirror: Reflections for teacher education. Paper presented at the Annual Meeting of the American Educational Research Association, San Diego, CA.

Lanoux, C., \& O’Hara, E. (1999). Deconstructing Barbie: Using creative drama as a tool for image making in pre-adolescent girls. Stage of the Art, 10(2), 8-13.

Larkin, B. R. (2001). “Can we act it out?” The Reading Teacher, 54(5), 478-81.

Linds, Warren. (Fall, 1998). Theatre of the oppressed: Developing a pedagogy of solidarity? Theatre Research in Canada, 177-192.

McCaslin, N. (2000). Creative drama in the classroom and beyond. New York: Longmann.

Ministry of Education. (1998). The arts: Ontario curriculum, Grade 1-8. Ontario: Queen's Printer for Ontario.

O’Neill, C. (1997). Drama worlds: A framework for process drama. Portsmouth, NH: Heinemann. 
O'Toole, J., \& Burton, B. (2002). Cycles of harmony: Action research into the effects of drama on conflict management in schools. Applied Theatre Researcher, 3.

Paterson, D.L., \& Weinberg, M. (Summer, 1996). We are all theatre: An interview with Augusto Boal. High Performance, 18-23.

Schutzman, M., \& Cohen-Cruz, J. (Eds.) (1994). Playing Boal: Theatre, therapy, activism. London: Routledge.

Siks, G. B. (1983). Drama with children. New York: Harper and Row.

Somers, J. (1996). Drama and theatre in education: Contemporary research. North York: Captus Press.

Taylor, L. (1965). An introduction to dramatics for children. MN: Burgess Publishing Company.

Torrance, E. P. (1975). Sociodrama as a creative problem-solving approach to studying the future. Journal of Creative Behavior, 9, 182-195.

Warren, B. (1993). Using the creative arts in therapy. London: Routledge.

Way, B. (1967). Development through drama. Atlantic Highlands, NJ: Humanities Press.

Widdows, J. (1996). Drama as an agent for change: Drama, behaviour and students with emotional and behavioural difficulties. Research in Drama Education, 1, 65-78. 
